\title{
Estimation of the meatness and fatness of 9- and 12-week-old Mulard ducks on the basis of selected live body measurements*
}

\author{
J. Książkiewicz and A. Mazanowski \\ Department of Waterfowl Breeding, Dworzyska Poultry Research Center \\ 62-022 Światniki $n /$ Warta, Poland
}

(Received 30 August 1993; accepted 17 September 1993)

\begin{abstract}
In 80 Mulard ducks (crossing of Muscovy drakes with Pekin ducks) at 9- and 12-weeks of age the relationships between alive body measurements and live body weight and percentage content of breast and legs muscles, skin with subcutaneous fat, abdominal and intestinal fat and bones in the carcass were determined.

According to the multiple regression equations the following parameters are useful for estimating the percentage of meat in 9-and 12-week-old living Mulard ducks: thorax lenght, shank length, breast circumference and breast muscle thickness. The fat content can be estimated on the basis of body weight, arm length, thorax length, sternum crest length and breast depth.
\end{abstract}

KEY WORDS: Mulard duck, body measurements, meatness, fatness

\section{INTRODUCTION}

Sternum crest length and breast muscle thickness are used as meatness indicators in the selection of living ducks from domestic breeding lines (Mazanowski, 1989). These and other body measurements of ducks are, along with body weight, independent variables in multiple regression equations used to estimate the amount of meat or fat in the body of birds (Bochno et al., 1988).

Mulard ducks from the crossing of Muscovy drakes (Cairina moschata L.) with Pekin ducks (strain A44 derived from Anas platyrhynchos L.) are either killed at 9 week of age, or are kept for 12 weeks for fatty livers (Mazanowski et al., 1992; Schubert et al., 1984). In comparison with Pekin ducks, Mulard ducks are

* This study was financed through grant No. 504259101 from the Committee for Scientific Research 
characterized by a higher dressing percentage, higher percentage of breast muscle and a lower percentage of skin plus subcutaneous fat (Pingel, 1991; Schubert et al., 1984). Because of the differences between the breeds in tissue composition (Górski, 1987; Mazanowski et al., 1992; Pingel, 1991) and body conformation as expressed by the indices of bulkiness, compactness and leg length (Książkiewicz and Mazanowski, 1993) there is a need for improved methods of evaluating meatness and fatness of ducks on the basis of body measurements.

The purpose of this study was to determine the relationship between body measurements of 9 and 12-week-old Mulard ducks with parameters determined after slaughter, i.e. dressing percentage and the percentage of meat, fat and bones in the dressed carcass. A second objective was to use multiple regression analysis to identify body dimensions that permit assessment of the meatness and fatness of live ducks.

\section{MATERIAL AND METHODS}

Eighty Mulard ducks were raised in a closed house with controlled environmental conditions. For the first 3 weeks they were fed a balanced feed containing $18.4 \%$ crude protein and $2680 \mathrm{kcal} \mathrm{ME} / \mathrm{kg}$, in following weeks feeds containing 11.7 and $12.9 \%$ of CP and 2587 and $2521 \mathrm{kcal} \mathrm{ME} / \mathrm{kg}$, respectively.

At the age of 9 or 12 weeks all the ducks were fasted $18 \mathrm{~h}$ and weighed. Twenty drakes and 20 ducks with body weights close to the average for the group were selected and measured according to the procedure described by Książkiewicz and Kontecka (1993). The birds were then slaughtered and plucked. After cooling at $4^{\circ} \mathrm{C}$ for $18 \mathrm{~h}$, the carcasses were dressed and the abdominal and intestinal fat was dissected and weighed. Dissection analysis was carried out according to the method of Ziołecki and Doruchowski (1989). The skin plus the subcutaneous fat were removed from the dressed carcasses without neck and wings, and the breast and leg muscles and the bones were separated and weighed.

The data was subjected to variance analysis and the relationships among the particular traits were estimated using common phenotypic correlation coefficients (r). Ten measurements of live ducks that were best related to meatness or fatness were chosen (Table 1) and used as independent variables $x_{1}$ to $x_{10}$ to calculate the multiple regression equations. The dependent variables ( $\mathrm{Y}$ and $\mathrm{Z})$ in these equations were the percentage of breast and leg muscles in a dressed carcass with neck and the percentage of skin plus subcutaneous fat, abdominal and intestinal fat in the carcass, respectively. Since the differences between Mulard drakes and ducks in terms of body weight, dimensions and tissue components are very small (Książkiewicz and Mazanowski, 1993; Mazanowski et al., 1992), the calculations were carried out jointly for birds of both sexes. 
TABLE 1

Body weight $(\mathrm{g})$ and body dimensions $(\mathrm{cm})$ in both sexes of Mulard ducks

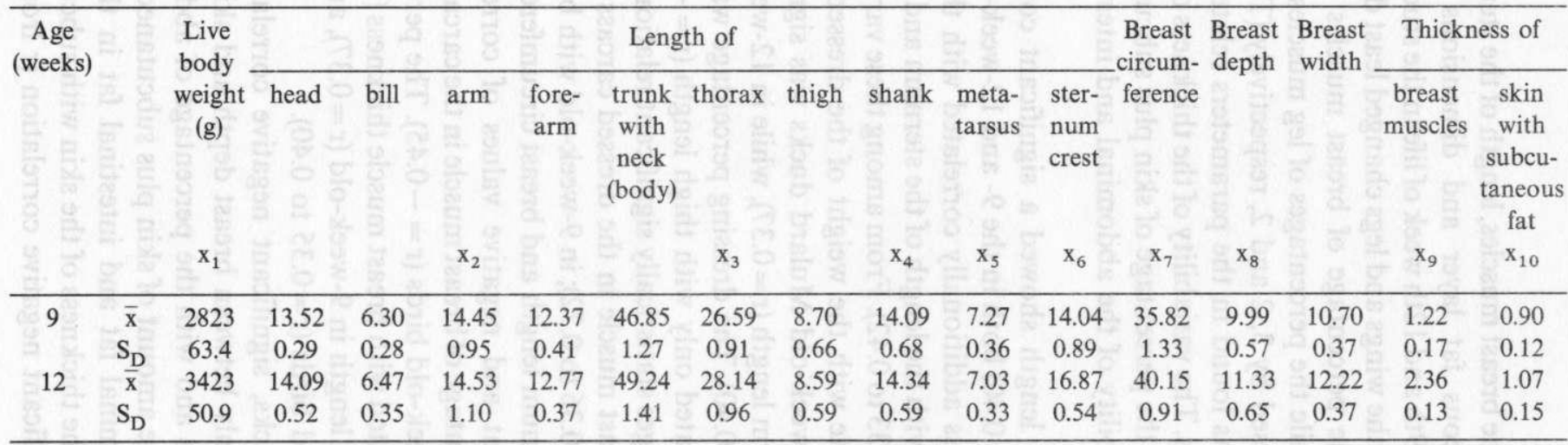

$\mathrm{x}_{1}$ to $\mathrm{x}_{2}$ - independent variables of multiple regression equations for evaluation (in \%) meat and fat 


\section{RESULTS}

The thickness of the breast muscles, length of the sternal crest, thickness of the skin with subcutaneous fat layer and dimensions of the chest increased significantly between 9 th and 12 th week of life in the studied Mulard ducks (Table 1). The dimensions of the wings and legs changed least during this period. During the same interval, the percentage of breast muscles in the carcass increased significantly $(8 \%)$, while the percentages of leg muscles, skin with subcutaneous fat, and bones decreased by 3,2 and 2, respectively (Table 2). At both ages the highest variability was found in the parameters related to fatness both in live ducks and in carcasses. The variability of the thickness of skin with subcutaneous fat reached $14.3 \%$, of the percentage of skin plus subcutaneous fat in the carcass $12.9 \%$ and the variability of the abdominal and intestinal fat content reached $60 \%$.

Body and thorax length showed a significant correlation with live body weight ( $\mathrm{r}$ from 0.36 to 0.40 ) both in the 9- and 12-week-old ducks. In 9-week old birds body weight was additionally correlated with the length of the forearm, while in 12-week old with the length of the sternum and circumference and width of the breast ( $\mathrm{r}$ from 0.33 to 0.42 ). From among these variables, only thorax length was found to correlate with the weight of the dressed carcass with neck. The dressed carcass of 9-week-old Mulard ducks was significantly and postitively correlated with forearm length $(\mathrm{r}=0.37)$, while in 12 -week-old ducks with breast muscle thickness $(\mathrm{r}=0.40)$. The dressing percentage was, however, significantly and negatively correlated only with thigh length $(r=-0.32)$.

In ducks of both ages statistically significant relationships were found among the percentage of breast muscle in the dressed carcass and the thickness of the breast muscle ( $r$ from 0.36 to 0.72 ); in 9-week-old with bill length $(r=0.39)$ and in 12-week-old with sternum length and breast circumference ( $\mathrm{r}$ from 0.33 to 0.50 ). Statistically significant and negative values of correlation coefficients were obtained for the percentage of breast muscle in the carcass with shank length in 9$(\mathrm{r}=-0.42)$ and 12 -week-old birds $(\mathrm{r}=-0.45)$. The percentage of muscle in legs was negatively correlated with breast muscle thickness $(r=-0.51)$ and positively correlated with shank length in 9-week-old $(\mathrm{r}=0.37)$, and with body and thorax lengths in 12-week-old birds $(r=0.35$ to 0.40$)$.

In 9-week-old ducks, significant negative correlations ( $\mathrm{r}$ from -0.39 to -0.53 ) were found only between breast depth and skin plus subcutaneous fat content in the carcass and with the percentage of abdominal fat. However, in 12-week-old ducks, the amount of skin plus subcutaneous fat in the carcass and the amount of abdominal fat and intestinal fat in the body were positively correlated only with the thickness of the skin with subcutaneous fat ( $\mathrm{r}$ from 0.33 to 0.46 ), while a significant negative correlation ( $\mathrm{r}$ from -0.33 to -0.56 ) was 
TABLE 2

Weight of eviscerated carcass with neck, dressing percentage, the content of some fat in the live body weight and composition of the carcasses with neck in both sexes of mulard ducks

\begin{tabular}{|c|c|c|c|c|c|c|c|c|c|}
\hline \multirow{2}{*}{$\begin{array}{c}\text { Age } \\
\text { (weeks) }\end{array}$} & & \multirow{2}{*}{$\begin{array}{c}\text { Weight of } \\
\text { eviscerated } \\
\text { carcass with } \\
\text { neck, g }\end{array}$} & \multirow{2}{*}{$\begin{array}{c}\text { Dressing } \\
\text { percentage } \\
\%\end{array}$} & \multicolumn{2}{|c|}{ Content in live body weight, $\%$} & \multicolumn{4}{|c|}{ Content in carcass with neck, $\%$} \\
\hline & & & & $\begin{array}{c}\text { abdominal } \\
\text { fat }\end{array}$ & $\begin{array}{c}\text { intestinal } \\
\text { fat }\end{array}$ & $\begin{array}{l}\text { breast } \\
\text { muscles }\end{array}$ & $\begin{array}{l}\text { thigh and } \\
\text { lower-thigh }\end{array}$ & $\begin{array}{c}\text { skin with } \\
\text { subcutaneous } \\
\text { fat }\end{array}$ & bones \\
\hline \multirow[t]{2}{*}{9} & $\overline{\mathrm{x}}$ & 1825 & 64.64 & 0.75 & 0.55 & 14.07 & 17.81 & 16.23 & 25.23 \\
\hline & $\mathrm{S}_{\mathrm{D}}$ & 52.67 & 1.37 & 0.33 & 0.28 & 2.04 & 1.33 & 2.09 & 1.13 \\
\hline \multirow[t]{2}{*}{12} & $\overline{\mathrm{x}}$ & 2243 & 65.53 & 0.46 & 0.26 & 22.01 & 14.95 & 13.98 & 23.10 \\
\hline & $\mathrm{S}_{\mathrm{D}}$ & 69.01 & 1.85 & 0.27 & 0.16 & 1.74 & 0.94 & 1.77 & 1.05 \\
\hline
\end{tabular}


found with head and bill lengths, body and thorax lengths, sternum length and breast depth.

Both at 9 and 12 weeks the bone content in the carcass was significantly and positively dependent on the forearm length ( $\mathrm{r}$ from 0.32 to 0.37 ) and negatively correlated with breast muscle thickness ( $\mathrm{r}$ from -0.39 to -0.55 ). At 9 weeks the bone content was additionally correlated with thorax length $(r=0.38)$ and breast width $(r=0.40)$.

Among the multiple regression equations (Table 3) used to estimate the percentage of meat in the carcasses of 9-week-old Mulard ducks before slaughter, number 3 deserves attention. Its independent variables are thorax length and breast muscle thickness. In 12-week-old birds, equation number 8 may be of use; it takes into account thorax length, shank length and breast circumference. Equation 5 can be used to estimate the percentage of fat in the carcasses of live 9-week-old ducks; in this equation body weight, thorax length and breast depth are independent variables. The same estimate can be made in 12-week-old ducks using equation 12 which takes into account body weight, arm length and sternum length. All the regression coefficients in the proposed equations are statistically significant at $\mathrm{P} \leqslant 0.05$ or 0.01 . The equations for estimating the percentage of meat have higher values of multiple correlation coefficients in 9-week-old than in 12-week-old ducks, while the equations for estimating the fat content have lower coefficients in younger than in older birds.

\section{DISCUSSION}

The average weight of Mulard ducks of both sexes at 9 weeks of age was $231 \mathrm{~g}$ lower, while at 12 weeks $115 \mathrm{~g}$ higher than of the hybrids studied at the same age by Kołodziejowa and Kołodziej (1969). Mazanowski et al. (1992) reported higher body weights of ducks phase fed with feeds containing varied amounts of crude protein and metabolizable energy. Trettner (1985) showed that not only nutrition, but the genotype of the parents are important factors in determining the weight and body composition of Mulard ducks.

All the body measurements of the Mulard ducks were intermediate between those of Pekin ducks (Bochno et al., 1988; Książkiewicz and Kontecka, 1993; Lewczuk et al., 1992; Wawro et al., 1988) and Muscovy drakes (Książkiewicz and Kontecka, 1994). Górski (1987) found similar shank, sternum crest and breast depth in 12-week-old ducks as in this study, but smaller breast circumferences and shank lengths. Slow growth of the head, wings and legs was also found by Wawro et al. (1988) in Pekin ducks between 9 and 12 weeks of age, while rapid development of the breast in Mulards during this period was found by Górski (1989). 
TABLE 3

Multiple regression equations for the estimation (in \%) on alive ducks of meat $(\mathrm{Y})$ and fat $(\mathrm{Z})$ content in carcass and multiple correlation coefficients (R)

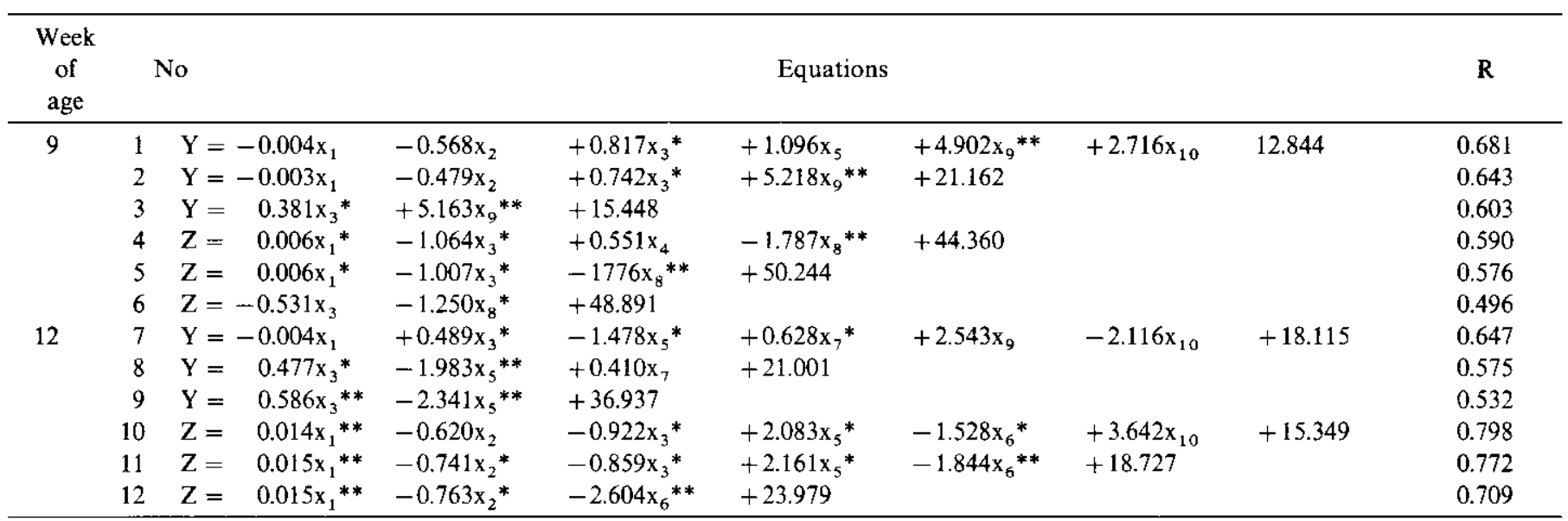

Explanation for symbols are given in Table 1

*,** - regession coefficients significant at $\mathrm{P} \leqslant 0.05$ or 0.01 
The high muscle and low fat content in the carcasses of hybrids from crossing Muscovy drakes with Pekin ducks was also found in other studies (Górski, 1987; Mazanowski et al., 1992; Pingel, 1991; Trettner, 1985; Schubert et al., 1984). Similar breast and leg muscle contents as those obtained in this study were found by Mazanowski et al. (1992) in 9- and 12-week-old hybrids, in 12-week-old birds by Górski (1987), while Trettner (1985) found a lower breast muscle content in 9-week-old ducks. The percentage of skin plus subcutaneous fat found in the current study was lower than in papers cited earlier.

The results of many studies undertaken to identify traits of live Pekin type ducks that permit to estimate the tissue composition of dressed carcass show that meat weight is best and positively correlated with body length, breast muscle thickness, sternum crest length and breast width and circumference (Bochno et al., 1988; Górski, 1987, 1989; Książkiewicz and Kontecka, 1992), while fat weight is correlated with breast muscle thickness, sternum crest length and breast circumference. The correlation coefficients determined by these authors varied depending both on the material used, body proportions, age and sex, as well as on the number of birds in each experiment. The correlation coefficients presented in this report were estimated in relation to the relative values of carcass components and were smaller than those reported by other authors (Bochno et al., 1988; Górski, 1989) in comparison to carcass weight.

The relationships determined in this study support the conclusions reached in studies on Pekin type ducks (Książkiewicz, 1993a,b; Książkiewicz and Kontecka, 1993) which showed that the highest degree of correlation is found between the percentage of breast muscles in the carcass and the thickness of these muscles ( $r$ from 0.38 to 0.63 ), sternum crest length ( $r$ from 0.41 to 0.60 ) and breast circumference ( $\mathrm{r}$ from 0.20 to 0.33 ); between leg muscle content and thorax length $(\mathrm{r}=0.38)$ and breast muscle thickness $(\mathrm{r}=-0.30)$. In other studies the percentage of skin plus subcutaneous fat or abdominal fat in the carcass was significantly and negatively correlated with other body measurements than reported here, i.e. arm and shank lengths or breast width (Książkiewicz, 1993 a), which is due to the high variability of traits related to fatness in ducks. Multiple regression equations permitting to determine in live birds the amount of meat and fat in carcass of various breeding strains of Pekin ducks were developed by Bochno et al. (1988). These equations take into account similar parameters as those used in this study for Mulard ducks, i.e. body weight, sternum crest length, breast muscle thickness, breast depth and thorax length. Bochno et al. (1988) obtained higher values of multiple correlation coefficients because the dependent variable in their equations was total amount of meat or fat and not, as in this study, the percentage of these components in the carcass. 


\section{CONCLUSIONS}

Statistically significant values of correlation coefficients were obtained among head, wing, leg and thorax measurements of living 9- and 12-week-old Mulard ducks with their live body weight and percentages of breast and leg muscles as well as skin plus subcutaneous fat, abdominal fat, intestinal fat and bone content in carcasses.

Multiple regression equations were used to identify the following parameters for estimating the percentage of meat in 9-and 12-week-old living Mulard ducks: thorax length, shank length, breast circumference and breast muscle thickness; the fat content can be estimated on the basis of body weight, arm length, thorax length, sternum crest length and breast depth.

\section{REFERENCES}

Bochno R., Lewczuk A., Janiszewska M., Mazanowski A., Wawro K., 1988. Zastosowanie równań regresji wielokrotnej do oceny umięśnienia i otłuszczenia kaczek. Acta Acad. Agric. Tech. Olst, Zoot. 31, 197-203

Górski J., 1987. Ocena efektów krzyżowania mieszańców pochodzących po kaczkach piżmowych i Pekin oraz wzrost i rozwój kaczek piżmowych. Inst. Hod. i Tech. Prod. Zwierz. WSR.P Siedlce, 1-22 (Report)

Górski J., 1989. Badania porównawcze tempa wzrostu oraz wpływu kojarzenia międzyrodowego kaczek Pekin na masę ciała, budowę i wartość rzeżną mieszańców. Wyd. WSR-P Siedlce, 27, 1-136 (Thesis, mimeograph)

Kołodziej L., Kołodziej H., 1969. Sprawdzenie przydatności mieszańców kaczora piżmowego z kaczką Pekin do produkcji stłuszczonych wątrób. Post. Drob. 11 (1), 11-18

Książkiewicz J., 1993a. Badania nad otłuszczeniem kaczek z dwóch rodów mięsnych. Rocz. Nauk. Zoot. 20,2

Książkiewicz J., 1993b. Wskaźniki zawartości mięśni piersiowych lub nóg w tuszkach kaczek z dwóch rodów hodowlanych. Rocz. Nauk. Zoot. 20, 2

Książkicwicz J., Kontecka H., 1992. The relations between body dimensions and tissue content of duck from experimental strain. In: Proc. 9th International Symposium on Waterfowl, Pisa, pp. 237-239

Książkiewicz J., Kontecka H., 1993. Zależności między masą i wymiarami ciała a niektórymi składnikami tuszek u kaczek w typie Pekina z grup zachowawczych. Rocz. AR Pozn. 44, 31-43

Książkiewicz J., Kontecka H., 1994. Zmiany zależności między wymiarami ciała a składnikami tkankowymi tuszek u kaczorów piżmowych w 8, 10 i 12 tygodniu życia. Rocz. AR Pozn. 45 (in press)

Książkiewicz J., Mazanowski A., 1993. The relationship between duck (hybrids Muscovy x Pekin) body weight, some measurements and liver weight after fattening. In: Proc. of Workshop on Quality and Standarization of the Waterfowl Product, Pawlowice

Lewczuk A., Bochno R., Wawro E., 1992. Wartość rzeźna kaczek piżmowych i rodu A-44 kaczek rasy Pekin. Pr. Mat. Zoot. 42, 83-90

Mazanowski A., 1989. Selection auf Fleischansatz bei Enten. 32. Internationale Geflügelvortragstagung. Züchtung und Mastgeflügel. Leipzig, 57-65

Mazanowski A., Bernacki Z., Korytkowska H., Kokoszyński D., 1992. Wpływ fazowego żywienia 
w okresie odchowu na wartość cech użytkowych i skład tkankowy tuszek mieszańców kaczora piżmowego z kaczką w typie Pekina. Zesz. nauk. ATR Bydgoszcz (in press)

Pingel H., 1991. Improving carcass and meat quality of waterfowl. World Poultry 9, 22-23

Schubert Chr., Pingel H., Trettner K., Bochno R., 1984. Vergleichende Untersuchungen zur Lebendmasseentwicklung und Schlachtkörperzusammensetzung von Enten, Warzen- und Kreuzungsenten. Fleisch 38, 138-140

Trettner K., 1985. Schlachtleistung verschiedener Wassergeflügelarten. 30. Internationale Geflügelvortragstagung. Neue Erkenntnisse zur Production von Geflügelfleisch. Leipzig, 300308 Wawro E., Brzozowski W., Michalik D., 1988. Badania nad wzrostem masy i wymiarów ciała kaczek. Acta Acad. Agric. Tech. Olst., Zoot., 31, 181-187

Ziołecki J., Dóruchowski W., 1989. Metoda oceny wartości rzeźnej drobiu. Ed. COBRD, Poznań

\section{STRESZCZENIE}

Przyżyciowa ocena umięśnienia i otluszczenia 9- i 12-tygodniowych kaczek Mulard na podstawie niektórych wymiarów ciala

U 80 kaczek Mulard, pochodzących z kojarzenia kaczorów piżmowych z kaczkami w typie Pekin, oznaczono w 9 i 12 tygodniu życia zależności między przyżyciowymi wymiarami glowy, kończyn i tułowia a masą ciala oraz procentową zawartością w tuszce mięśni piersiowych i nóg oraz skóry z tłuszczem podskórnym, tłuszczu sadełkowego i okołojelitowego a także kości.

$\mathrm{Na}$ podstawie równań regresji wielokrotnej do przyżyciowego oszacowania zawartości mięsa u 9 lub 12 tygodniowych Mulardów wytypowano następujące cechy: długość tulowia, długość skoku, obwód klatki piersiowej i grubość mięśni piersiowych, a do zawartości tluszczu: masę ciała, dlugość ramienia, długość tułowia, długość grzebienia mostka i głębokość klatki piersiowej. 